\title{
Tindakan Main Hakim Sendiri (Eigen Richting) dalam Terjadinya Pencurian Sapi di Madura
}

\author{
Wartiningsih \\ Fakultas Hukum Universitas Trunojoyo Madura \\ Wartiningsih@trunojoyo.ac.id
}

\begin{abstract}
Vigilante action takes place in Madura and elsewhere. There appears to have been a paradigm shift in society, which once upheld the values of humanity. Public response outside the vigilante actors shows their satisfaction if the perpetrators of theft are judged by the masses.This research will analyze vigilante action from 2 aspect that is, society aspect will be analyzed with legal system theory from Lawrence M. Friedman. While from the police will be analyzed from the institutional aspects based on the theory of Chambliss \& Saidman. This type of research is sociological juridical research with factual approach. The data and information obtained are qualitatively analyzed for fact-finding, which then leads to problem-identification and ultimately towards problem-solving. Based on the result and discussion, the recommendation given by the researcher is the need of counseling and awareness from the society that vigilante action is unlawful. For the police there needs to be consolidation and a high commitment to enforce the law because non-enforcement or "omission" can not be justified from the theoretical aspect as well as aspects of the practice that violate the rights of suspects and is an obstacle for the suspect in an attempt to obtain justice.
\end{abstract}

Keywords: eigen richting, cow theft, omission.

\begin{abstract}
Abstrak
Tindakan main hakim sendiri terjadi di Madura maupun di daerah lain. Nampaknya telah terjadi perubahan paradigma dalam masyarakat, yang dahulu menjunjung nilai-nilai kemanusiaan. Respon masyarakat di luar pelaku main hakim sendiri menujukkan kepuasannya jika pelaku pencurian dihakimi massa. Penelitian ini akan menganalisis tindakan main hakim sendiri dari 2 (dua) aspek yaitu, aspek masyarakat akan dianalisis dengan teori sistem hukum dari Lawrence M. Friedman. Sedangkan dari kepolisian akan dianalisis dari aspek kelembagaan berdasarkan teori Chambliss \& Saidman.Jenis penelitian ini adalah penelitian yuridis sosiologis dengan pendekatan fakta. Data dan informasi yang diperoleh dianalisis secara kualitatif untuk menemukan fakta (fact-finding), yang kemudian menuju pada identifikasi (problem-identification) dan pada akhirnya menuju kepada penyelesaian masalah (problem-solution). Berdasarkan hasil dan pembahasan, rekomendasi yang diberikan oleh peneliti adalah perlu penyuluhan dan penyadaran dari masyarakat bahwa tindakan main hakim sendiri adalah perbuatan yang melawan hukum. Untuk kepolisian perlu ada
\end{abstract}


konsolidasi dan komitmen yang tinggi untuk bisa melakukan penegakan hukum karena non-enfocerment atau "pembiaran"tidak dapat dibenarkan dari aspek teori maupun aspek praktik yang melanggar hak tersangka dan merupakan hambatan bagi tersangka dalam upaya memperoleh keadilan.

\section{Kata Kunci : tindakan main hakim, pencurian sapi, pembiaran.}

\section{Pendahuluan}

Fenomena yang marak akhirakhir ini adalah pelaku tindak pidana dihakimi massa tanpa melalui proses peradilan pidana. Hampir setiap hari masyarakat mendengar begal motor dihakimi massa dengan dipukuli dan dibakar hingga mati. Hal itu terjadi di Tangerang Selatan, Magelang, Indramayu, Asal Kecamatan Lintang, Kabupaten Empat Lawang, Sumatra selatan, Kedung Pandan, Jabon Sidoardjo.

Sistem Nasional Pemantauan Kekerasan (SNPK) mencatat tak kurang dari 6.807 konflik. Konflik kekerasan yang terjadi antara Januari- September 2014, bentuk main hakim sendiri menduduki angka tertinggi (3.925), sengketa sumber daya (786), perseteruan identitas (767), pilkada (467), tata kelola pemerintahan (456), separatisme (41) dan lainnya (338).

Dari youtube bisa dilihat tayangan "Maling Sapi Dibakar
Hidup"(https://www.youtube.com

/watch?v=7zs5bjlrVfw).

Yang lebih memprihatinkan, sebagian masyarakat di Madura berlaku "hukum" jika pencuri yang tertangkap basah mencuri sapi maka akan dihakimi massa dengan dipukuli dan dibakar sampai mati dan tanpa ada kelanjutannya. Dengan kata lain aparat penegak hukum tidak memproses bagaimana seharusnya siapa yang harus bertanggung jawab atas kematian si pencuri tersebut.

\section{Permasalahan}

Berdasarkan uraian tersebut di atas maka yang menjadi permasalahan dalam penelitian ini adalah :

a) Dalam menghadapi pencurian sapi apa yang menjadi alasan melakukan tindakan main hakim sendiri ?

b) Mengapa aparat penegak hukum melakukan 
"pembiaran" terhadap pelaku (massa) ?

\section{Tujuan Penelitian}

Tujuan penelitian ini dilakukan adalah (1) Untuk mengetahui apa yang menjadi alasan masyarakat melakukan tindakan main hakum sendiri atau eigen richting terhadap pelalu pencurian sapi di Madura dan (2) Untuk mengetahui mengapa aparat penegak hukum (polisi) melakukan "pembiaran" terhadap terjadinya tindakan main hakim sendiri oleh masyarakat dalam hal terjadinya pencurian sapi di Madura.

\section{Manfaat Penelitian}

Hasil penelitian ini dapat dijadikan sebagai : (1) dasar bagi aparat penegak hukum (Polres Bangkalan) untuk melakukan treatment misalnya penyuluhan hukum agar masyarakat memiliki pengetahuan dan kesadaran hukum bahwa tindakan main hakim adalah perbuatan melawan hukum dan melanggar hak pelaku untuk mendapatkan peradilan secara memadai; dan (2) dapat menjadi bahan koreksi dan konsolidasi aparat penegak hukum dari sisi kelembagaan. Perlu pemahaman bahwa upaya penegakan hukum memang diperlukan kerja keras dan komitmen yang kuat bagi aparat penegak hukum.

\section{Metode Penelitian}

\section{1) Jenis Penelitian}

Pada penelitian ini adalah penelitian yuridis-sosiologis. Yuridis-sosiologis artinya suatu penelitian yang dilakukan terhadap keadaan nyata masyarakat atau lingkungan masyarakat dengan maksud dan tujuan untuk menemukan fakta (fact-finding), yang kemudian menuju pada identifikasi (problem-identification) dan pada akhirnya menuju kepada penyelesaian masalah (problemsolution) (Soerjono Soekanto, $1982: 10)$.

\section{2) Lokasi Penelitian}

Penelitian ini akan dilakukan di Kecamatan Pademawu Kabupaten Pamekasan. Lokasi ini dipilih karena pernah membakar 2 (dua) pencuri sapi (https://wn.com/dua_mobil_pencu ri_sapi_dibakar).

\section{3) Pendekatan Penelitian}


Oleh karena tujuan penelitian ini adalah untuk memperoleh gambaran seutuhnya tentang ide, persepsi, pendapat terhadap tindakan main hakim sendiri yang semuanya tidak dapat diukur dengan angka-angka maka pendekatan yang digunakan adalah pendekatan fakta.

\section{4) Proses Pengumpulan dan} Analisis Informasi

\section{a) Proses Pengumpulan Data} Primer dan Data Sekunder

Data primer dalam penelitian ini adalah data yang diperoleh langsung dari orang atau sekelompok orang yang terlibat dalam terjadinya tindakan main hakim sendiri dalam terjadinya pencurian sapi. Sedangkan data sekunder dalam penelitian ini adalah data yang ada di Polsek di mana tindakan main hakim sendiri itu berlangsung, beberapa literatur dan hasil penelitian yang relevan.

\section{b) Analisis Data dan Informasi}

Data baik primer dan data sekunder yang berhasil ditemukan akan dianalisis dengan menggunakan tolok ukur (Ade Saptomo, 2007 :36) : peraturan perundang-undangan yang berkaitan dengan tindakan main hakim sendiri; (2) aparat kepolisian ; (3) sarana prasarana yang tersedia; (4) sosial budaya masyarakat yang mempraktikkan tindakan main hakim sendiri dalam kasus pencurian sapi. Analisis yang digunakan adalah analisis kualitatif yaitu menekankan pada analisis induktif yang mengembangkan konsep dan menghimpun fakta, tidak melakukan pengujian hipotesis melalui perhitungan angka-angka (Prastowo, 2012 :45).

\section{5) Penafsiran dan Penarikan Kesimpulan}

Salim mengembangkan pendapat Mile dan Huberman (2006: 20-24), menyebutkan ada 3 (tiga) langkah pengolahan data kualitatif, yakni reduksi data (data reduction), penyajian data (data display), dan penarikan kesimpulan (conclusion drawing and verification). Dalam pelaksanaannya reduksi data, penyajian data, dan penarikan kesimpulan/verifikasi, merupakan sebuah langkah yang sangat luwes, dalam arti tidak terikat oleh batasan kronologis. Secara keseluruhan langkah-langkah 
tersebut saling berhubungan selama dan sesudah pengumpulan data, sehingga model dari Miles dan Huberman disebut juga sebagai model interaktif.

\section{Hasil dan Pembahasan}

\section{Alasan Masyarakat Melakukan Tindakan Main Hakim Sendiri atau Eigen Richting Terhadap Pelaku Pencurian Sapi di Madura.}

\section{a) Pengertian Main Hakim Sendiri}

Apabila direnungkan, perbuatan main hakim sendiri merupakan perwujudan ketidakpercayaan dan kekecewaan pelaku terhadap penyelesaian yang diberikan oleh pengadilan atas suatu kasus tertentu. Ketidakpuasan korban atau keluarga korban yang terusik kepentingannya dan upaya untuk mengembalikan kepentingannya oleh pengadilan tidak sesuai dengan yang diharapkan. Tindakan main hakim sendiri adalah peradilan oleh massa terhadap korban. Nampaknya telah terjadi pergeseran nilai yang semula masyarakat menjunjung nilai-nilai kemanusiaan yang mana respon masyarakat (bukan pelaku main hakim sendiri) tidak menunjukkan penyesalan bahkan menunjukkan kepuasannya apabila pencuri dihakimi massa.

Kamus Besar Bahasa Indonesia memberkan pengertian main hakim sendiri : menghakimi orang lain tanpa memedulikan hukum yang ada (biasanya dilakukan dengan pemukulan, penyiksaan, pembakaran, dan sebagainya(https://kbbi.kemdikbu d.go.id/entri/Main\%20hakim\%20s endiri). Peradilan yang seharusnya menjadi jalan penyelesaian persoalan hukum agar tidak berkembang menjadi konflik yang mengganggu ketertiban masyarakat. Dalam kaitan ini Satjipto Raharjo menegaskan bahwa fungsi pengadilan akan efektif jika memiliki 4 (empat) prasyarat yaitu :

1) Kepercayaan (masyarakat) bahwa di tempat itu mereka akan memperoleh keadilan seperti mereka kehendaki;

2) Kepercayaan (masyarakat) bahwa pengadilan merupakan lembaga yang mengekspresikan nilai-nilai 
kejujuran, mentalitas yang tidak korup dan nilai-nilai utama lainnya;

3) Bahwa waktu dan biaya yang mereka keluarkan tidak siasia;

4) Bahwa pengadilan merupakan tempat bagi orang untuk benar-benar memperoleh perlindungan hukum (Satjipto, 2001 : 55 ). Dalam buku I, sebagai ketentuan umum, Pasal 49 KUHP yang mengatur tentang hal-hal yang menghapuskan, mengurangi, atau memberatkan pidana. Seseorang yang melakukan pembelaan terpaksa, ia akan dipidana apabila pembelaan yang diberikan terhadap pelaku “melampaui" batas. Dalam konteks main hakim sendiri maka apa yang dilakukan oleh massa , karena menghadapi maraknya pencurian sapi kemudian menempuh peradilan dan mengeksekusi sendiri pelaku, bukan merupakan alasn menghapuskan pidana.

Alasan masyarakat melakukan tindakan main hakim sendiri ini dapat dianalisis dari kultur hukum yang dikemukakan oleh Friedman. Kultur hukum yang dikonsepsikan oleh Friedman adalah"...the legal culture is the element of social attitude and value..."(Friedman, 1975 : 15). Kultur hukum ini merupakan permintaan atau tuntutan yang datangnya dari masyarakat atau pemakai jasa hukum. Wujud dari kultur hukum ini bermacam-macam, apakah dengan jalan adu kekuatan fisik yang bisa diawasi orang lain. Tuntutan tersebut didorong oleh faktor kepentingan, ide, sikap, keyakinan, harapan, dan pendapat mengenai hukum. Untuk menjawab tuntutan masyarakat yang diwujudkan dalam tindakan main hakim sendiri ini dapat dilihat jawaban dari 18 (delapan belas) responden yaitu : (1) 11 (sebelas) orang menjawab masyarakat tidak percaya tarhadap kinerja aparat kepolisian sehingga setuju apabila pelaku "dimassa" dan; (2) 7 (tujuh) orang menjawab tidak setuju maka pelaku harus diadili melalui proses peradilan pidana. 
Banyaknya masyarakat (11 orang) yang menuntut pelaku untuk "dimassa" mencerminkan pendapat masyarakat terhadap hukum. Sikap setuju ini terlihat dari jawaban responden bahwa : polisi seringkali terlambat di TKP, jika diproses melalui peradilan membutuhkan waktu yang lama dan sanksi yang dijatuhkan oleh hakim kepada pelaku tidak memberikan efek jera.

Sebagaimana dikemukakan Satjipto Raharjo menegaskan bahwa fungsi pengadilan akan efektif jika memiliki 4 (empat) prasyarat yaitu : (a) Kepercayaan (masyarakat) bahwa di tempat itu mereka akan memperoleh keadilan seperti mereka kehendaki; (b) Kepercayaan (masyarakat) bahwa pengadilan merupakan lembaga yang mengekspresikan nilai-nilai kejujuran, mentalitas yang tidak korup dan nilai-nilai utama lainnya; (c) Bahwa waktu dan biaya yang mereka keluarkan tidak sia-sia; (d) Bahwa pengadilan merupakan tempat bagi orang untuk benar-benar memperoleh perlindungan hukum (Satjipto, Ibid.).

b) Pertanggungjawaban Pidana Para Pelaku Main Hakim Sendiri.

Main hakim sendiri merupakan perbuatan pidana, maka terhadap pelaku dapat dipertanggungjawabkan atas perbuatan yang dilakukan. Oleh karena pelaku lebih dari satu maka untuk memperhitungkan secara proposional tentang sanksi yang akan dijatuhkan maka diperlukan ajaran tentang penyertaan.

Dasar hukum untuk menangani masyarakat yang melakukan tindakan main hakim sendiri adalah : (1) Pasal 170 KUHP yang mengatur tentang : secara terang-tarangan dan dengan tenaga menggunakan kekerasan terhadap orang atau barang; (2) Pasal 351 KUHP tentang penganiayaan biasa. Apabila dikualifikasi sebagai penganiayaan berat diatur dalam Pasal 354 KUHP; (3) Pasal 338 KUHP : tentang pembunuhan.
c) Customary Law dalam Sistem Hukum Indonesia 
Menyadari bahwa Indonesia terbentuk dari beragam suku dengan budayanya masingmasing. Hal tersebut membawa konsekuensi adanya beragam hukum adat yang berlaku di Indonesia. Daniel S. Lev yaitu budaya hukum sendiri terdiri dari 2 (dua) komponen yaitu :

1) Nilai-nilai hukum prosedural yang berupa cara-cara pengaturan masyarakat dan manajemen konflik;

2) Nilai-nilai hukum substansial yang berupa asumsi-asumsi fundamental mengenai distribusi maupun penggunaan sumber-sumber di dalam masyarakat, terutama mengenai apa yang adil dan tidak adil menurut masyarakat (Daniel S. Lev dalam Prisma, $2000: 104)$.

Berkaitan dengan apa yang adil dan tidak adil menurut masyarakat kiranya relevan untuk mengkaitkan salah satu karakter dari masyarakat Madura yang menjunjung tinggi "rasa keadilan" sebagaimana diuraikan oleh Mien Akhmad Rifa`i sebagai berikut :

“...reaksi orang Madura dapat tidak kepalang tanggung. Bila diketahui bahwa keadilan yang diharapkan tidak terjadi sesuai dengan norma-norma umum yang berlaku, (cetak tebal oleh Penulis) mereka akan berani nabang (secara harfiah berarti mengejar). Untuk itu mereka akan berusaha mempengaruhi jalan pengadilan supaya pihaknya dimenangkan dalam perkara, sekalipun dengan jalan menyediakan sogokan pada pihak-pihak yang bisa dibeli..." (Mien A. Rifa'i, 2007 : 243).

Dalam konteks tindakan main hakim sendiri nampaknya masyarakat meminta pada aparat kepolisian untuk bertindak "di luar hukum" sebagaimana dimuat dalam suatu tulisan dari The Rynard Law Firm sebagai berikut

"Other authors and researchers would point to the lack of communities' ability to come to consensus. Bittner (1967) and Goldstein (1977) discuss this lack of consensus. Bittner (1967) particularly notes the "demands" of one part of the community that the police contain a perceived undesirable area through the use of discretionary tactics that would be found unacceptable outside the contained area. Klockars (1980) also notes a desire from the community that the police behave in an extralegal manner in some circumstances." (The Rynard Law Firm, 2014 : 41).

Aparat Penegak Hukum (Polisi) Melakukan "Pembiaran"

a) Fungsi Hukum sebagai Pengendalian Sosial 
Hukum sebagai alat kontrol sosial memberikan arti bahwa ia merupakan sesuatu yang dapat menetapkan tingkah laku manusia. Tingkah laku ini dapat didefenisikan sebagai sesuatu yang menyimpang terhadap aturan hukum. Sebagai akibatnya, hukum dapat memberikan sanksi atau tindakan terhadap si pelanggar.

Berkaitan dengan fungsi hukum ini, agar hukum dapat bekerja sesuai dengan fungsinya maka masyarakat harus tergerak untuk menyerahkan konflikkonflik yang dihadapannya kepada hukum. Untuk mewujudkan hal tersebut Friedman menyatakan bahwa hukum harus dibicarakan dari segi struktur, substansi juga dari segi kulturnya seperti yang dinyatakan : "A legal system in actual operation is a complex organism in which structure, substance, and culture interact".(Friedman, 1975: 16).

Menurut Friedman, struktur hukum adalah pola yang memperlihatkan bagaimana hukum itu dijalankan menurut ketentuan formalnya. Struktur ini memperlihatkan bagaimana pengadilan, perbuatan hukum, dan institusi-institusi lainnya serta proses hukum itu berjalan dan dijalankan. Substansi hukum adalah peraturan-peraturan yang dipakai oleh para pelaku hukum pada waktu melakukan perbuatanperbuatan serta hubungan hukum (Friedman, 1975 : 14). Sedangkan Kultur hukum ini merupakan permintaan atau tuntutan yang datangnya dari masyarakat atau pemakai jasa hukum. Wujud dari kultur hukum ini bermacammacam, apakah dengan jalan adu kekuatan fisik yang bisa diawasi orang lain. Tuntutan tersebut didorong oleh faktor kepentingan, ide, sikap, keyakinan, harapan, dan pendapat mengenai hukum.

\section{b) Teori-teori Penegakan Hukum}

Penegakan hukum adalah mewujudkan ide-ide, konsep dalam kehidupan nyata berkaitan dengan hal tersebut. Muladi mendefinisakan penegakan hukum sebagai “...merupakan usaha untuk menegakkan normanorma hukum dan sekaligus nilainilai yang ada di belakang norma tersebut. Dengan demikian para penegak hukum harus memahami benar-benar spirit hukum( legal spirit) yang mendasari peraturan 
hukum yang harus ditegakkan..." (Muladi, 2002 : 69).

Joseph Golstein, sebagaimana dikutip oleh Muladi, penegakan hukum dapat dibedakan menjadi 3 (tiga) bagian yaitu : (Rochim, 2012 : 72) (1) Total enforcement : adalah penegakan hukum secara total sebagaimana yang dirumuskan oleh hukum pada substansinya (substantif law of crime). Penagakan hukum secara total ini tidak dapat dilaksanakan karena aparat kepolisian sendiri dibatasi secara ketat oleh berbagai aturan; (2) Full enforcement : dalam penegakan inipun aparat tidak dapat melaksanakan secara penuh karena terdapat berbagai keterbatasan seperti waktu, sarana dan prasarana, sumberdaya manusia sehingga melakukan diskresi; (3) Actual enforcement : dalam penegakan inipun tidak tertutup kemungkinan aparat kepolisian melakukan penyimpangan misalnya penyimpangan hak-hak tersangka ketika melakukan penangkapan dan penahanan.

Berdasarkan teori tersebut dapat dimaknai bahwa penegakan hukum apapun pasti mengandung sisi kelemahan dengan kata lain maka penegakan harus dilakukan. Dengan demikian tidak akan "membiarkan" main hakim sendiri dan penindakan tertahap pelakunya harus dilakukan.

\section{c) Hambatan Penegakan Hukum}

Berdasarkan teori penegakan hukum yang sudah diuraikan di atas memang dimungkinkan aparat kepolisian dapat melakukan penyimpangan. Penyimpangan yang dimaksud dalam teori-teori penegakan hukum di atas masih dalam lingkup apa yang disebut diskresi. Pengertian diskresi sendiri dibatasi oleh : (1) Asas keperluan bahwa tindakan itu benar-benar diperlukan;

Tindakan yang diambil harus benar-benar untuk kepentingan tugas kepolisian. Asas tujuan, bahwa tindakan yang paling tepat untuk meniadakan suatu gangguan atau tidak terjadinya suatu kekhawatiran terhadap akibat yang lebih besar; (3) Asas keseimbangan bahwa dalam mengambil tindakan harus dipertimbangkan keseimbangan 
antara sifat tindakan atau sasaran yang digunakan dengan besar kecilnya gangguan atau berat ringannya suatu obyek yang harus ditindak (Prasetyo, 2011 : 23 ) Melakukan non- enforcement atau melakukan pembiaran adalah tidak dapat dibenarkan. Hambatan dalam penegakan hukum ini dapat dilihat dari 2 (dua) sisi yaitu dari sisi aparat kepolisian dan dari sisi masyarakat.

\section{Kajian Kepolisian Resort dari Aspek Kelembagaan}

Polisi pada hakikatnya bisa dilhat sebagai hukum yang hidup, karena memang di tangan polisi itulah hukum dapat diwujudkan. Berkaitan dengan hal tersebut Satjipto menyatakan bahwa hukum dibuat ditujukan untuk menciptakan ketertiban dalam masyarakat. Satjipto menjelaskan pula bahwa upaya menciptakan ketertiban masyarakat salah satunya adalah melawan kejahatan. Pada akhirnya polisi itulah yang akan menentukan apa yang dilakukan sebagai penegakan ketertiban, siapa yang harus ditundukkan dan siapa yang harus dilindungi. Pada sisi yang lain Satjipto dengan mengutip

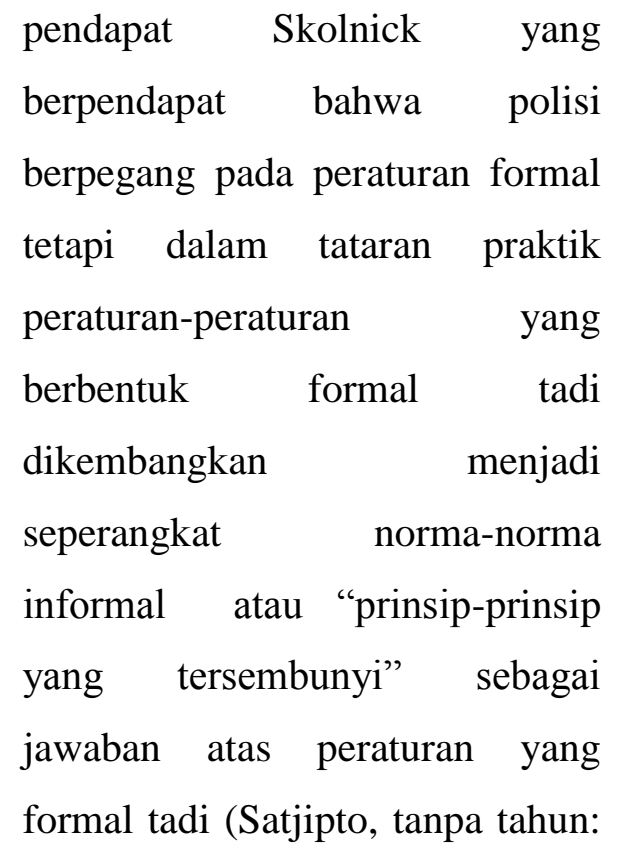
99)

Dilihat dari sisi kepolisian, menarik yang dinyatakan oleh Muladi (2002 : 70), disadari bahwa penegakan hukum sebagai bagian dari sub sistem sosial maka pengaruh lingkungan menjadi amat menentukan. Kepolisian sebagai organisasi penegakan hukum sudah barang tentu akan menentukan bagaimana proses penegakan hukum itu dijalankan. Hal tersebut sejalan dengan Chambliss \& Seidman menentukan bahawa akan terjadi goal substitution dan goal displacement dari organisasi kepolisian dalam menjalankan tugasnya dengan selamat di 
tengah-tengah masyakat (Satjipto, 2009 : 131).

Berdasarkan hasil wawancara dari 15 (lima belas) responden didapatkan jawaban bahwa semua menjawab karena sulitnya menemukan barang bukti dan saksi. Kinerja polisi adalah perwujudan dari hukum yang berlaku. Polisi melaksanakan hukum formal yang ada melalui proses memilah dan memilih. Pada akhirnya polisi itulah yang akan menentukan apa yang dilakukan sebagai penegakan ketertiban, siapa yang harus ditundukkan dan siapa yang harus dilindungi. Pada sisi yang lain Satjipto mengutip pendapat Skolnick yang berpendapat bahwa polisi berpegang pada peraturan formal tetapi dalam tataran praktik peraturan-peraturan yang berbentuk formal tadi dikembangkan menjadi serangkat norma-norma informal atau “prinsip-prinsip yang tersembunyi" sebagai jawaban atas peraturan yang formal tadi (Satjipto, Ibid.).

Memang dipahami baik total enforcement, full enforcement dan actual enforcement bukan penegakan hukum yang sempurna karena aparat kepolisian menghadapi berbagai peraturan yang membatasi dan berbagai keterbatasan. Akan tetapi untuk mencapai penegakan hukum yang ideal harus disertai dengan kesadaran bahwa penegakan hukum merupakan sub sistem sosial, sehingga pengaruh lingkungan cukup berarti, seperti pengaruh perkembangan politik, ekonomi, sosial budaya, hankam, iptek, pendidikan dan sebagainya (Muladi, Ibid.) Non-enforcement atau "pembiaran" merupakan pelanggaran terhadap prinsipprinsip negara hukum sebagaimana tersurat dan tersirat dalam UUD 1945 dan asas-asas hukum yang berlaku di lingkungan bangsa-bangsa beradab.

Pelanggaran Hak-hak Tersangka untuk Memperoleh Peradilan yang Memadai

a) Undang-undang Nomor 8 Tahun 1981 sebagai Dasar Pengaturan Sistem Peradilan Pidana dan Hakhak Tersangka dalam KUHAP 


\begin{abstract}
Undang-undang No. 8 Tahun 1981 tentang Kitab Undangundang Hukum Pidana telah diatur beberapa prinsip khususnya yang berkaitan dengan tindakan main hakim sendiri yaitu tersangka wajib mendapatkan bantuan hukum, terdakwa berhak diadili dalam pengadilan yang adil dan tidak memihak (fair trial) dan dalam persidangan dengan hadirnya terdakwa. Secara normatif, nampak KUHAP memiliki spirit menjunjung HAM. Apa yang diatur dalam HAM dipandang dapat mewujudkan asas peradilan uang jujur dan adil (principle of a fair trial) dan mencegah munculnya tindak pidana gangguan terhadap proses memperoleh keadilan (obstruction of justise ).
\end{abstract}

Paradigma baru dalam sistem peradilan pidana adalah tersangka bukan sebagai obyek tetapi sebagai subyek dimana dalam setiap pemeriksaan harus diperlakukan dalam kedudukan manusia yang mempunyai harkat, martabat dan harga diri. Tersangka tidak terlihat sebagai obyek yang dirampas hak asasi dan harkat martabat kemanusiaannya dengan sewenang-wenang. Seorang tersangka tidak dapat diperlakukan dengan sekehendak hati pemeriksa dengan alasan bahwa dia telah bersalah melakukan suatu tindak pidana, ia bukanlah pelaku kejahatan sebelum ada putusan yang menyatakan pelaku bersalah sebagaimana berlaku asas praduga tidak bersalah (presumption of innocence). Di antara beberapa hak tersangka maka hak yang berkaitan hak pelaku sebagai korban main hakim sendiri adalah hak tersangka untuk diadili di sidang pengadilan yang terbuka untuk umum (Pasal 64 KUHAP). Terpenting pula bahwa main hakim yang dilakukan oleh masyarakat merupakan tindak pidana gangguan terhadap proses untuk memperoleh keadilan. Semua putusan pengadilan hanya sah dan mempunyai kekuatan hukum apabila diucapkan di sidang terbuka untuk umum.

$\begin{array}{lll}\begin{array}{l}\text { Penanganan } \\ \text { Hakim }\end{array} & \begin{array}{c}\text { Tindakan } \\ \text { Sendiri }\end{array} & \begin{array}{c}\text { Main } \\ \text { Oleh }\end{array} \\ \text { Masyarakat } & & \end{array}$

a) Sosialisasi/Penyuluhan 
Melihat maraknya tindakan main hakim sendiri yang dilakukan oleh masyarakat, khususnya kepada pelaku pencurian sapi maka perlu digiatkan kembali penyuluhan atau sosialisasi pada masyarakat. Perlu disampaikan kepada masyarakat atas hak-hak tersangka untuk berhak diadili dalam peradilan yang terbuka, pengadilan yang fair dan adil.

\section{b) Penegakan Hukum Terhadap Pelaku Tindakan Main Hakim Sendiri (Eigen Richting).}

Penegak kepolisian wajib memiliki komitmen terhadap prinsip-prinsip negara hukum sebagaimana tersurat dan tersirat dalam UUD 1945 dan asas-asas hukum yang berlaku di lingkungan bangsa-bangsa beradaplah (seperti 'The Basic Principles of the Independent of Judiciary 1985). Disadari memang untuk mengumpulkan barang bukti dan saksi sebagai syarat untuk dapat diproses sangat sulit. Misalnya saja tidak ada satu pun orang yang bersedia menjadi saksi dan seharusnya menjadi tantangan bagi aparat polisi.
Polisi sebagai "ujung tombak" sistem peradilan pidana, dengan memegang prinsip-prinsip di atas yaitu dengan memproses para pelaku tindakan main hakim sendiri diharapkan akan mengurangi bahkan mencegah tindakan tersebut.

\section{Simpulan}

Berdasarkan analisis atas permasalahan penelitian ini maka dapat disimpulkan sebagai berikut

1) Alasan yang mendasari masyarakat melakukan tindakan main hakim sendiri adalah ketidakpercayaan masyarakat terhadap kinerja aparat penegak hukum karena : (a) Polisi seringkali datang terlambat di TKP; (b) Apabila diproses melalui peradilan membutuhkan waktu yang lama; (c) Sanksi yang dijatuhkan hakim tidak memberikan efek jerea.

2) Polisi melakukan "pembiaran" dalam arti masyarakat yang mestinya bertanggung jawab secara pidana dibebaskan dari sanksi. Hal tersebut polisi 
merasa kesulitan mencari

bukti dan saksi.

Sedangkan saran yang dapat diberikan adalah :

1) Perlu digiatkan kembali peyuluhan hukum/ sosialisasi tentang hak-hak tersangka untuk diadili dalam sidang yang terbuka untuk umum dan diadili oleh pengadilan yang adil dan fair. Perlu penyadaran kepada masyarakat bahwa main hakim sendiri adalah perbuatan melawan hukum. Sosialisasi atau penyuluhan dapat dilakukan dengan memanfaatkan pola kepemimpinan pedesaan di Madura yaitu melalui kalebun sebagai pemimpim formal, kyai seorang pengajar pesantren atau po-seppo (sesepuh) yaitu orang yang dihormati secara adat.

2) Secara kelembagaan, kepolisian perlu konsolidasi dan komitmen untuk memegang prinsip-prinsip negara hukum sebagaimana tersurat dan tersirat dalam UUD 1945 dan asas-asas hukum yang berlaku di lingkungan bangsa-bangsa beradap. Kesulitan yang ada harus dijadikan tantangan bagi polisi dalam upaya penegakan hukum.

\section{Daftar Pustaka}

Andi Prastowo, 2012, Metode Penelitian Kualitatif dalam Perspektif Rancangan Penelitian, Yogyakarta, ArRuzz Media.

Ade Saptomo, 2007, Pokok-pokok Metodologi Penelitian Hukum, Surabaya, Unesa University Press.

Agus Salim,2006, Teori dan Paradigma Penlitian Sosial, , Yogyakarta, Tiara Wacana.

Lawrence M. Friedman, 1975, The Legal System, A Social Science Perspective, New York: Russel Sage Foundation.

Muladi, 2002, Hak Azazi Manusia, Politik, dan Sistem Peradilan Pidana",Semaran, Badan Penerbit UNDIP.

Mien AkhmadRifa`i, 2007, Manusia MaduraPembawaan, Perilaku, Etos Kerja, dan Pandangan Hidupnya Seperti Dicitrakan Peribahasanya, Nuansa Aksara, Yogyakarta. 
Satjipto Rahardjo, 1993, Ilmu Hukum, Bandung, Citra Aditya Bakti.

\section{Hukum dan}

Perubahan Sosial, Alumni, Bandung, 1986.

Daniel S. Lev, "Peradilan dan Kultur Hukum Indonesia" dalam Prima No. 6 Tahun II Desember 1973, dalam Esmi Warassih, "Pranata Hukum Sebuah Telaah Sosiologis', Semarang, 2005.

Hukum sebagai Alat Kontrol Sosial (Tool of Social Control)

http://www.referensimakala h.com/2012/09/fungsihukum-sebagai-alat-kontrolsosial-tool-of-socialcontrol.html Diakses tgl. 15 April 2017.

The Rynard Law Firm, 2014, "Police

Discretion"'http://www.ryna rdlaw.com/Pages/PoliceDisc retion.aspx diunduh tgl 12 Okt 2014.

https://wn.com/dua_mobil_pencur i_sapi_dibakar diakses tgl. 22 April 2017.

Kitab Undang-undang Hukum Pidana (KUHP).

Undang-undang Nomor 8 Tahun 1981 tentang Kitab Undangundang Hukum Acara Pidana. 